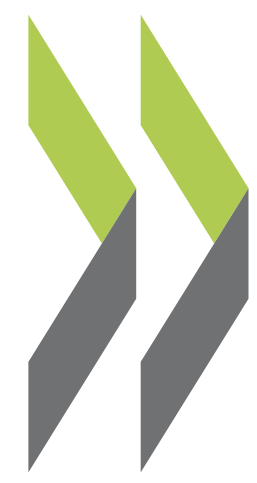

OECD Economics Department Working Papers No. 844

Macroeconomic Impact Patrick Slovik, of Basel III Boris Cournède 
Organisation de Coopération et de Développement Économiques

Organisation for Economic Co-operation and Development

14-Feb-2011

ECONOMICS DEPARTMENT

English - Or. English

MACROECONOMIC IMPACT OF BASEL III

ECONOMICS DEPARTMENT WORKING PAPER No. 844

By Patrick Slovik and Boris Cournède

All economics Deparment Working Papers are available through OECD's internet website at http:/www.oecd.org/eco/Workingpapers 


\section{SUMMARY/RÉSUMÉ}

\section{Macroeconomic Impact of Basel III}

The estimated medium-term impact of Basel III implementation on GDP growth is in the range of -0.05 to -0.15 percentage point per annum. Economic output is mainly affected by an increase in bank lending spreads as banks pass a rise in bank funding costs, due to higher capital requirements, to their customers. To meet the capital requirements effective in 2015 (4.5\% for the common equity ratio, $6 \%$ for the Tier 1 capital ratio), banks are estimated to increase their lending spreads on average by about 15 basis points. The capital requirements effective as of 2019 (7\% for the common equity ratio, $8.5 \%$ for the Tier 1 capital ratio) could increase bank lending spreads by about 50 basis points. The estimated effects on GDP growth assume no active response from monetary policy. To the extent that monetary policy will no longer be constrained by the zero lower bound, the Basel III impact on economic output could be offset by a reduction (or delayed increase) in monetary policy rates by about 30 to 80 basis points.

JEL classification: G21; G28; E52.

Keywords: Basel accord; Basel III; Bank; Financial Intermediaries; Bank Regulation; Bank Lending; Monetary Policy; Interest Rates; Bank Capital Requirements.

$* * * * * * * * * *$

\section{Impact macro-économique de Bâle III}

L'impact estimé à moyen terme de la mise en conformité avec les règles de Bâle III sur la croissance du PIB est de l'ordre de $-0,05$ à $-0,15$ point de pourcentage par an. L'effet sur l'activité économique provient principalement de ce que les banques augmentent leurs marges de crédit afin de compenser la hausse de leurs coûts de financement provoquée par le durcissement des exigences de capital. Pour répondre aux exigences de fonds propres en 2015 (4,5\% pour le ratio d'actions ordinaires, $6 \%$ pour le ratio de fonds propres de base), les banques devraient augmenter leurs marges de crédit d'environ 15 points de base en moyenne. Les exigences de capital en vigueur à compter de 2019 (7\% pour le ratio d'actions ordinaires, $8,5 \%$ pour le ratio de fonds propres de base) pourraient augmenter les marges de crédit d'environ 50 points de base. Les effets estimés sur la croissance du PIB n'incorporent aucune réponse de la politique monétaire. Pour autant que la politique monétaire ne se heurte plus au plancher zéro des taux nominaux, l'impact de Bâle III sur la production économique pourrait être compensé par une réduction (ou un retard avant l'augmentation) des taux de la politique monétaire d'environ 30 à 80 points de base.

Classification JEL: G21; G28 ; E52.

Mots-clés: Accord de Bâle ; Bâle III ; Banque ; Intermédiaires financiers ; Réglementation bancaire ; Crédit bancaire ; Politique monétaire ; Taux d'intérêt ; Réglementation des fonds propres bancaires.

Copyright $\odot$ OECD, 2011.

Application for permission to reproduce or translate all, or part of this material should be made to: Head of Publications Service, OECD, 2 rue André-Pascal, 75775 Paris Cedex 16, France. 


\section{TABLE OF CONTENTS}

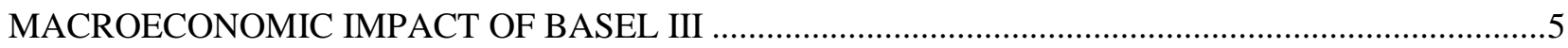

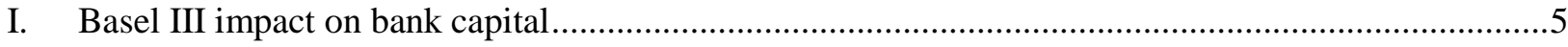

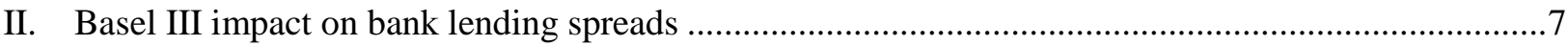

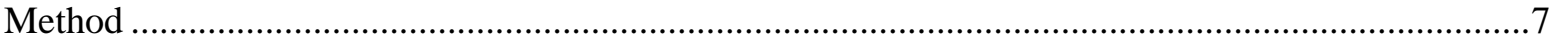

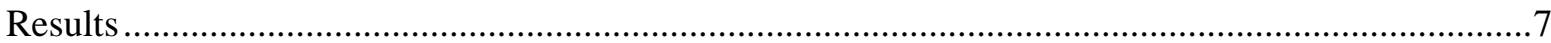

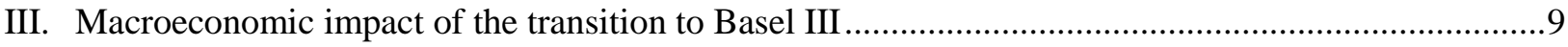

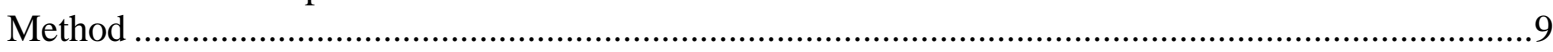

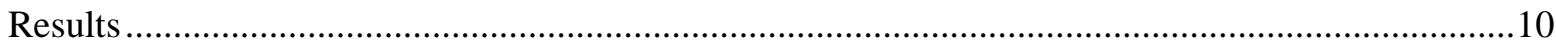

IV. Comparison with the estimates of the Macroeconomic Assessment Group ......................................11

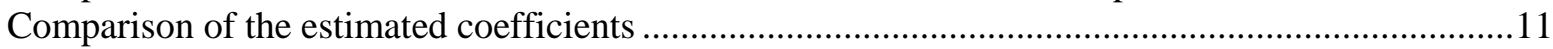

Comparison of the Basel III impact assessments ..........................................................................

V. Other factors related to the Basel III macroeconomic impact .........................................................12

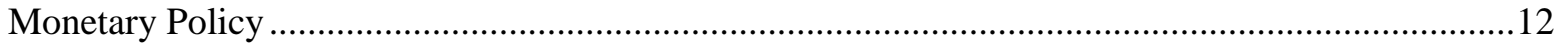

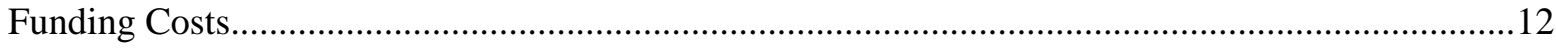

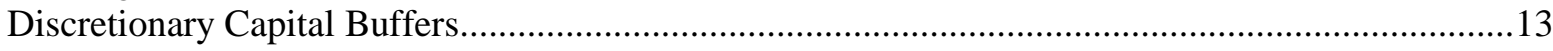

\section{Tables}

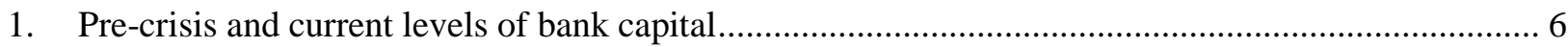

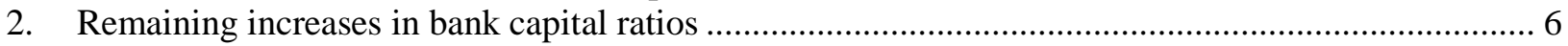

3. Increase in bank lending spreads for a one percentage point increase in bank capital....................... 8

4. The impact of Basel III on bank lending spreads ........................................................................ 8

5. Macroeconomic impact of a 100 basis point increase in bank lending rates ..................................... 9

6. Macroeconomic impact of a one percentage point increase in bank capital ratios ........................... 10

7. Macroeconomic impact of 2015 Basel III capital requirements .................................................... 10

8. Macroeconomic impact of 2019 Basel III capital requirements ................................................. 10

9. Macroeconomic impact of a 100 basis point reduction in policy rates ............................................ 12

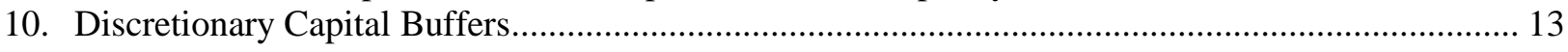


ECO/WKP(2011)13 
ECO/WKP(2011)13

\title{
MACROECONOMIC IMPACT OF BASEL III
}

\author{
by
}

\author{
Patrick Slovik and Boris Cournède ${ }^{1}$
}

1. The main objective of this study is to estimate the medium-term impact on economic output of the announced Basel III capital requirements using a consistent approach across the three main OECD economies. The analysis suggests an average impact on annual GDP growth in the range of -0.05 to -0.15 percentage point during a five-year period. The next two sections focus on quantifying the impact of Basel III capital requirements on bank capital levels (Section I) and bank lending spreads (Section II). An analysis of the impact of Basel III capital requirements on GDP level and growth is presented in Section III. Section IV compares these results with the estimates presented by the Macroeconomic Assessment Group (MAG) established by the Financial Stability Board (FSB) and Basel Committee on Banking Supervision (BCBS). The concluding remarks, in Section V, highlight other factors related to Basel III impact estimates such as the possibility of a monetary policy response and considerations related to bank funding costs and bank capital buffers.

\section{Basel III impact on bank capital}

2. The recent Basel III agreement ${ }^{2}$ raises the minimum capital requirements for common equity capital from $2 \%$ to $4.5 \%$ of risk-weighted assets and the Tier 1 ratio from $4 \%$ to $6 \%$ effective as of 2015 . Subsequently, fully effective as of 2019 , banks will be required to add a conservation buffer of 2.5 percentage points on the top of common equity and Tier 1 capital ratios.

3. Already, prior to the agreement on the new Basel III regulation, banks had increased their capital ratios relative to the pre-crisis levels as a result of considerable market pressures. Table 1 shows that, relative to pre-crisis levels as of end-2006, ${ }^{3}$ banks in the United States, the euro area and Japan had by end-2009 increased their common equity ratio on average by 1.3 percentage points and their Tier 1 capital ratio on average by 1.5 percentage points. ${ }^{4}$

1. Patrick Slovik and Boris Cournède are economists in the OECD Economics Department. The authors are grateful to Jørgen Elmeskov and Sveinbjörn Blöndal for their useful comments, but retain responsibility for any remaining errors. The opinions expressed in this paper are those of the authors and do not necessarily reflect the views of the OECD or its member countries. Corresponding author: patrick.slovik@oecd.org.

2. Bank for International Settlements (2010), "Group of Governors and Heads of Supervision announces higher global minimum capital standards”, BIS Press Release, 12 September 2010, Basel.

3. Taking an average level of capital over the last three pre-crisis years (2004-2006) instead of end-2006 would have no material impact on the analysis (the differences in benchmark capital levels would be only about 0.1 percentage point).

4. The common equity ratio is approximated here by the ratio of tangible common equity to risk-weighted assets. 
Table 1. Pre-crisis and current levels of bank capital

\begin{tabular}{|c|c|c|c|c|c|}
\hline & \multicolumn{4}{|c|}{$\begin{array}{c}\text { Bank Capital } \\
\text { (percentages of risk-weighted assets) }\end{array}$} & \multirow{2}{*}{$\begin{array}{c}\Delta \text { Bank Capital } \\
\text { (percentage points) } \\
2006 \text { - } 2009 \text { Increase }\end{array}$} \\
\hline & 2006 & 2007 & 2008 & 2009 & \\
\hline \multicolumn{6}{|l|}{ United States } \\
\hline Tier 1 & 9.8 & 9.4 & 9.7 & 11.4 & 1.6 \\
\hline Common Equity & 8.6 & 8.3 & 8.4 & 10.5 & 1.9 \\
\hline \multicolumn{6}{|l|}{ Euro area } \\
\hline Tier 1 & 8.0 & 7.7 & 8.6 & 9.4 & 1.4 \\
\hline Common Equity & 6.8 & 6.6 & 7.3 & 8.0 & 1.2 \\
\hline \multicolumn{6}{|l|}{ Japan } \\
\hline Tier 1 & 5.4 & 5.6 & 5.6 & 6.9 & 1.5 \\
\hline Common Equity & 3.3 & 3.3 & 3.3 & 4.1 & 0.8 \\
\hline \multicolumn{6}{|c|}{ Average (unweighted) } \\
\hline Tier 1 & 7.7 & 7.6 & 8.0 & 9.2 & 1.5 \\
\hline Common Equity & 6.2 & 6.1 & 6.3 & 7.5 & 1.3 \\
\hline
\end{tabular}

Source: IIF ${ }^{5}$, Authors' calculations.

4. Considering that these improvements in common equity and Tier 1 ratios occurred due to market pressures for higher capital levels, the remaining efforts to meet the new Basel III requirements should be reduced by the increases already achieved. Taking the capital increases already achieved into account, until 2015 banks will need to increase their actual common equity ratio on average by about 1.2 percentage points and the Tier 1 capital ratio by about 0.5 percentage point (Table 2). To meet the capital requirements effective by 2019, which include the conservation buffer, banks will need to increase their common equity ratio on average by about 3.7 percentage points and the Tier 1 capital ratio by about 3.0 percentage points. The main recapitalisation efforts of banks will thus be directed towards the common equity ratio, ${ }^{6}$ which will therefore be the focus of the following examination of the macroeconomic impact of Basel III.

Table 2. Remaining increases in bank capital ratios

\begin{tabular}{|c|c|c|c|c|c|c|}
\hline & \multicolumn{3}{|c|}{$\begin{array}{c}\text { Capital Increase Required until } 2015 \\
\text { (percentage points) }\end{array}$} & \multicolumn{3}{|c|}{$\begin{array}{c}\text { Capital Increase Required until } 2019 \\
\text { (percentage points) }\end{array}$} \\
\hline & Required & Achieved & Remaining & Required & Achieved & Remaining \\
\hline \multicolumn{7}{|l|}{ United States } \\
\hline Tier 1 & 2.0 & 1.6 & 0.4 & 4.5 & 1.6 & 2.9 \\
\hline Common Equity & 2.5 & 1.9 & 0.6 & 5.0 & 1.9 & 3.1 \\
\hline \multicolumn{7}{|l|}{ Euro area } \\
\hline Tier 1 & 2.0 & 1.4 & 0.6 & 4.5 & 1.4 & 3.1 \\
\hline Common Equity & 2.5 & 1.2 & 1.3 & 5.0 & 1.2 & 3.8 \\
\hline \multicolumn{7}{|l|}{ Japan } \\
\hline Tier 1 & 2.0 & 1.5 & 0.5 & 4.5 & 1.5 & 3.0 \\
\hline Common Equity & 2.5 & 0.8 & 1.7 & 5.0 & 0.8 & 4.2 \\
\hline \multicolumn{7}{|l|}{ Average (unweighted) } \\
\hline Tier 1 & 2.0 & 1.5 & 0.5 & 4.5 & 1.5 & 3.0 \\
\hline Common Equity & 2.5 & 1.3 & 1.2 & 5.0 & 1.3 & 3.7 \\
\hline
\end{tabular}

Source: IIF, Authors' calculations.

5. Institute of International Finance (2010), "Interim Report on the Cumulative Impact on the Global Economy of Proposed Changes in the Banking Regulatory Framework", Washington, DC.

6. In the following sections bank capital or bank equity will refer to tangible common equity unless explicitly mentioned otherwise. 


\section{Basel III impact on bank lending spreads}

\section{Method}

5. The impact of Basel III on bank lending spreads is estimated based on accounting identities applied to aggregated banking sector balance sheets. For the purpose of the estimation, two categories of bank assets are considered: (i) Bank lending assets (AL) that comprise bank credit to households and non-financial corporations held on banking books, and (ii) Other bank assets (AO), which represent a residual category that comprises assets held on trading books, interbank assets, government bonds and other remaining assets. It is assumed that a bank can directly affect the pricing of AL by adjusting its lending spread. The pricing of AO is mainly market driven and it is therefore assumed that a bank cannot directly affect the pricing of these assets.

6. The balance-sheet identity presented in Equation (1) postulates that the return on bank assets is equal to bank funding costs, which are determined by the cost of liabilities and the cost of equity. Equation (2) incorporates a one percentage point increase in bank capital relative to risk-weighted assets. An increase in bank capital will affect bank liability and equity structures and as a consequence the overall bank funding cost. To compensate for the change in funding cost banks are assumed to adjust their lending spreads, while their costs of equity and debt financing are assumed to remain constant. Combining equations (1) and (2) leads to Equation (3), which shows the increase in bank lending spreads as a result of a one percentage point increase in the ratio of bank capital to risk-weighted assets.

$$
\begin{aligned}
& r_{t}^{A L} \times A L+r_{t}^{A O} \times A O=r_{t}^{L} \times L+r_{t}^{E} \times E \\
& r_{t+1}^{A L} \times A L+r_{t}^{A O} \times A O=r_{t}^{L} \times\left(L-\frac{R W A}{100}\right)+r_{t}^{E} \times\left(E+\frac{R W A}{100}\right) \\
& \left(r_{t+1}^{A L}-r_{t}^{A L}\right)=\frac{\left(r_{t}^{E}-r_{t}^{L}\right)}{A L} \times \frac{R W A}{100}
\end{aligned}
$$

Legend:

AL - Lending Assets to Total Assets (\%)

AO - Other Assets to Total Assets (\%)

L - Liabilities to Total Assets (\%)

E - Common Equity to Total Assets (\%)

RWA - Risk-weighted Assets to Total Assets (\%)

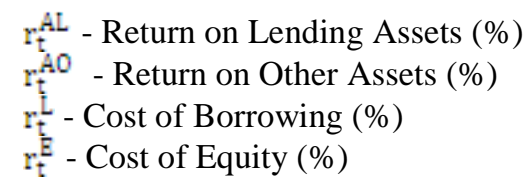

\section{Results}

7. The estimated sensitivities of bank lending spreads to a one percentage point increase in capital requirements are shown in Table 3. The input data are based on aggregated bank balance sheets ${ }^{7}$ averaged over the last three pre-crisis years (2004-2006). A one percentage point increase in the ratio of capital to risk-weighted assets will push up bank lending spreads by 14.4 basis points on average across the three

7. The aggregated bank data are sourced from the statistical appendix of the study by Institute of International Finance (2010), "Interim Report on the Cumulative Impact on the Global Economy of Proposed Changes in the Banking Regulatory Framework", Washington, DC. 
main OECD economies. The sensitivity will be comparatively higher in the United States (mainly due to a higher return on equity and a higher share of risk-weighted assets in bank balance sheets) and lower in Japan (mainly due to a lower return on equity and a higher share of lending assets in bank balance sheets).

Table 3. Increase in bank lending spreads for a one percentage point increase in bank capital

\begin{tabular}{|c|c|c|c|c|}
\hline & $\begin{array}{c}r_{t}^{E} r_{t}^{L} \\
\text { (basis points) }\end{array}$ & $\underset{\text { (percentages) }}{\mathrm{AL}}$ & $\underset{\text { (percentages) }}{\text { RWA }}$ & $\begin{array}{l}r_{t+1}^{A A L}-r_{t}^{A I} \\
\text { (basis points) }\end{array}$ \\
\hline United States & 12.7 & 47.5 & 76.4 & 20.5 \\
\hline Euro area & 9.4 & 35.4 & 53.9 & 14.3 \\
\hline Japan & 7.7 & 66.0 & 72.0 & 8.4 \\
\hline Average (unweighted) & & & & 14.4 \\
\hline Average (GDP weighted) & & & & 16.1 \\
\hline
\end{tabular}

Note: $\quad$ The input data of the estimation represent an average of the last three pre-crisis years (2004-2006) calculated based on aggregated bank balance sheets.

Source: Authors' estimates.

8. The potential impact of Basel III on bank lending spreads (Table 4) can be computed by combining the estimated bank lending spread sensitivities (Table 3) with the remaining bank capital increases described in Section I (Table 2). To meet the Basel III requirements effective as of 2015 banks would increase their lending spreads on average by approximately 15 basis points. To meet the Basel III requirements effective as of 2019 banks would increase their lending spreads on average by approximately 50 basis points.

9. Despite the difference in banking sector structures and in recapitalization needs across the three main OECD economies, the estimated increases in bank lending spreads fall in a relatively close range. Although Japan has the highest required capital increase, it will not result in the greatest rise in bank lending spreads because of the differences in lending-spread sensitivities. Considering the capital requirements effective as of 2015, the implied changes in bank lending spreads vary within a relatively narrow range of 12.3 to 18.6 basis points.

Table 4. The impact of Basel III on bank lending spreads

\begin{tabular}{lccccc}
\hline & \multicolumn{2}{c}{$\begin{array}{c}\text { Remaining Capital Increase } \\
\text { (percentage points) }\end{array}$} & & \multicolumn{2}{c}{$\begin{array}{c}\text { Increase in Bank Lending Spreads } \\
\text { (basis points) }\end{array}$} \\
\cline { 2 - 3 } \cline { 5 - 6 } & $\mathbf{2 0 1 5}$ & $\mathbf{2 0 1 9}$ & & $\mathbf{2 0 1 5}$ & $\mathbf{2 0 1 9}$ \\
\hline United States & 0.6 & 3.1 & & 12.3 & 63.6 \\
Euro area & 1.3 & 3.8 & & 18.6 & 54.3 \\
Japan & 1.7 & 4.2 & & 14.3 & 35.3 \\
Average (unweighted) & & & 15.1 & 51.1 \\
Average (GDP weighted) & & & & 15.6 & 52.9 \\
\hline
\end{tabular}

Source: Authors' estimates. 
ECO/WKP(2011)13

\section{Macroeconomic impact of the transition to Basel III}

\section{Method}

10. The medium-term macroeconomic impact of Basel III is estimated using adjusted semi-elasticities of the OECD New Global Model. ${ }^{8}$ The announced capital regulation represents a certain and long-lasting change; therefore, its effects on macroeconomic variables are best approximated by a sustained change in long-term interest rates. To account for this the short-term interest rate semi-elasticities of the OECD New Global Model are converted into their long-term interest rate equivalents. ${ }^{9}$ The impact on GDP is further scaled by the share of banks in total credit intermediation because the Basel III capital requirements affect the banking sector. ${ }^{10}$ The resulting semi-elasticities of the level of GDP to a 100 basis point increase in bank lending rates are shown in Table 5. The macroeconomic impact of the same-sized change in bank lending rates is the highest in the euro area in line with it having the highest share of bank credit intermediation, followed by Japan and the United States.

Table 5. Macroeconomic impact of a 100 basis point increase in bank lending rates

\begin{tabular}{|c|c|c|c|c|c|c|}
\hline & \multicolumn{5}{|c|}{$\begin{array}{c}\text { GDP level } \\
\text { (percentages) }\end{array}$} & \multirow{2}{*}{$\begin{array}{c}\text { GDP growth } \\
\text { (percentage points) } \\
\text { annual } \\
\end{array}$} \\
\hline & Year 1 & Year 2 & Year 3 & Year 4 & Year 5 & \\
\hline United States & -0.08 & -0.31 & -0.54 & -0.77 & -0.93 & -0.18 \\
\hline Euro area & 0.00 & -0.23 & -0.93 & -1.40 & -2.10 & -0.42 \\
\hline Japan & 0.00 & -0.33 & -0.50 & -1.17 & -1.33 & -0.27 \\
\hline Average (simple) & -0.03 & -0.29 & -0.66 & -1.11 & -1.45 & -0.29 \\
\hline Average (GDP weighted) & -0.03 & -0.28 & -0.69 & -1.08 & -1.45 & -0.29 \\
\hline
\end{tabular}

Note: $\quad$ The numbers include international spillover effects among the three economies. The spillover effect of a 100 basis point rise in lending rates on GDP level in the 5 th year is on average about -0.35 percentage point; the GDP weighted spillover effect is about -0.30 percentage point. The international spillovers have the highest impact on Japan, and the lowest impact on the United States. The analysis in the rest of this study takes these effects into account.

Source: Authors' estimates.

11. To derive the semi-elasticity of the level of GDP to a one percentage point increase in bank capital ratios, the estimates shown in Table 5 need to be scaled by the sensitivities of bank lending spreads to bank capital shown in Table 3. The resulting impact of a one percentage point increase in bank capital ratios on GDP level and growth are shown in Table 6. In the three main OECD economies, a one percentage point increase in the ratio of bank capital to risk weighted assets would result in an average impact on GDP level of $-0.20 \%$ five years after the implementation, which translates into a -0.04 percentage point impact on annual GDP growth.

8. For information on the OECD New Global Model, see K. Hervé et al. (2010), “The OECD’s New Global Model”, OECD Economics Department Working Paper No. 768.

9. This adjustment utilises equivalence coefficients between short-term and long-term interest rates underpinning the OECD financial conditions indices, suggesting that a one percentage point increase in short-term interest rates has the same effect on GDP as about a 0.3 percentage point increase in long-term rates. See S. Guichard, D. Haugh and D. Turner (2009),"Quantifying the effect of financial conditions in the euro area, Japan, the United Kingdom and the United States", OECD Economics Department Working Papers, No. 677 and S. Guichard and D. Turner (2008),"Quantifying the effect of financial conditions on US activity", OECD Economics Department Working Papers, No. 635.

10. In the United States, banks account for $23.6 \%$ of the total credit intermediation compared to $73.8 \%$ in the euro area and $52.6 \%$ in Japan. See Institute of International Finance (2010), "Interim Report on the Cumulative Impact on the Global Economy of Proposed Changes in the Banking Regulatory Framework", Washington, DC. 
Table 6. Macroeconomic impact of a one percentage point increase in bank capital ratios

\begin{tabular}{|c|c|c|c|c|c|c|}
\hline & \multicolumn{5}{|c|}{$\begin{array}{c}\text { GDP level } \\
\text { (percentages) }\end{array}$} & \multirow{2}{*}{$\begin{array}{c}\text { GDP growth } \\
\text { (percentage points) } \\
\text { annual }\end{array}$} \\
\hline & Year 1 & Year 2 & Year 3 & Year 4 & Year 5 & \\
\hline United States & -0.02 & -0.06 & -0.11 & -0.16 & -0.19 & -0.04 \\
\hline Euro area & 0.00 & -0.03 & -0.13 & -0.20 & -0.30 & -0.06 \\
\hline Japan & 0.00 & -0.03 & -0.04 & -0.10 & -0.11 & -0.02 \\
\hline Average (simple) & -0.01 & -0.04 & -0.10 & -0.15 & -0.20 & -0.04 \\
\hline Average (GDP weighted) & -0.01 & -0.05 & -0.11 & -0.17 & -0.22 & -0.04 \\
\hline
\end{tabular}

Source: Authors' estimates.

\section{Results}

12. The macroeconomic impact of Basel III can be computed by combining the estimated semi-elasticities outlined above (Table 5) with the estimated increase in bank lending spreads described in Section II (Table 4). On this basis, the Basel III requirements fully effective as of 2015 are estimated to reduce the level of GDP in the three main OECD economies on average by $-0.23 \%$ five years after the implementation by banks (Table 7). This figure translates into an approximate average impact on GDP growth of -0.05 percentage point per annum.

Table 7. Macroeconomic impact of 2015 Basel III capital requirements

\begin{tabular}{|c|c|c|c|c|c|c|}
\hline & \multicolumn{5}{|c|}{$\begin{array}{c}\text { GDP level } \\
\text { (percentages) }\end{array}$} & \multirow{2}{*}{$\begin{array}{c}\text { GDP growth } \\
\text { (percentage points) } \\
\text { annual } \\
\end{array}$} \\
\hline & Year 1 & Year 2 & Year 3 & Year 4 & Year 5 & \\
\hline United States & -0.01 & -0.04 & -0.07 & -0.10 & -0.11 & -0.02 \\
\hline Euro area & 0.00 & -0.04 & -0.17 & -0.26 & -0.39 & -0.08 \\
\hline Japan & 0.00 & -0.05 & -0.07 & -0.17 & -0.19 & -0.04 \\
\hline Average (simple) & 0.00 & -0.04 & -0.10 & -0.17 & -0.23 & -0.05 \\
\hline Average (GDP weighted) & 0.00 & -0.04 & -0.11 & -0.17 & -0.23 & -0.05 \\
\hline
\end{tabular}

Source: Authors' estimates.

13. If the Basel III requirements effective as of 2019 are considered, the macroeconomic effects will be larger (Table 8). In this case, the average impact on annual GDP growth is estimated to be about -0.15 percentage point. Once banks start to implement the 2019 capital requirements, which could also happen ahead of the schedule (i.e. in the run-up to 2015), the actual Basel III medium-term impact will be greater than the 2015 estimates in Table 7 and could reach up to the 2019 estimates in Table 8. On this basis, the impact of Basel III on annual GDP growth is estimated in the range of -0.05 to -0.15 percentage point over the medium term. ${ }^{11}$

Table 8. Macroeconomic impact of 2019 Basel III capital requirements

\begin{tabular}{|c|c|c|c|c|c|c|}
\hline & \multicolumn{5}{|c|}{$\begin{array}{c}\text { GDP level } \\
\text { (percentages) }\end{array}$} & \multirow{2}{*}{$\begin{array}{c}\text { GDP growth } \\
\text { (percentage points) } \\
\text { annual }\end{array}$} \\
\hline & Year 1 & Year 2 & Year 3 & Year 4 & Year 5 & \\
\hline United States & -0.05 & -0.20 & -0.34 & -0.49 & -0.59 & -0.12 \\
\hline Euro area & 0.00 & -0.13 & -0.51 & -0.76 & -1.14 & -0.23 \\
\hline Japan & 0.00 & -0.12 & -0.18 & -0.41 & -0.47 & -0.09 \\
\hline Average (simple) & -0.02 & -0.15 & -0.34 & -0.55 & -0.73 & -0.15 \\
\hline Average (GDP weighted) & -0.02 & -0.16 & -0.38 & -0.58 & -0.79 & -0.16 \\
\hline
\end{tabular}

Source: Authors' estimates.

11. The estimated macroeconomic impact is larger in the euro area than in Japan and the United States, mainly as a consequence of a greater share of bank credit intermediation in the euro area economy. 
ECO/WKP(2011)13

\section{Comparison with the estimates of the Macroeconomic Assessment Group}

\section{Comparison of the estimated coefficients}

14. The Macroeconomic Assessment Group (MAG) of the Financial Stability Board (FSB) and Basel Committee on Bank Supervision (BCBS) concluded, ${ }^{12}$ based on country-specific methodologies, that a one percentage point increase in the ratio of capital to risk-weighted assets results in a median increase in bank lending spreads of approximately 15 basis points. The estimate presented in this study of 14.4 basis points, based on a common methodology for the three main OECD economies, is almost identical. Thus, the sensitivity of bank lending spreads to bank capital presented in this study is consistent with the estimates of the Macroeconomic Assessment Group. Further, the MAG concluded that a one percentage point increase in capital to risk-weighted assets reduces the level of GDP by $-0.19 \%$ four and half years after the start of the implementation, implying a -0.04 percentage point impact on annual GDP growth. The estimated impact of a one percentage point increase in capital to risk-weighted assets on GDP level presented in this study is $-0.20 \%$ five years after the implementation, which is also equivalent to -0.04 percentage point impact on annual GDP growth. Hence, concerning the estimated impact of a one percentage point increase in bank capital ratios on the level and growth of GDP, the results of this study are well in line with the estimates of the Macroeconomic Assessment Group.

\section{Comparison of the Basel III impact assessments}

15. The main difference between the MAG study and the present analysis is in mapping of the estimated coefficients with the Basel III capital requirements. The MAG assessment assumes that the current benchmark level of common equity ratio is $5.7 \%$ of risk-weighted asset and will need to increase by 1.3 percentage points to meet the required $7 \%$ of risk-weighted asset. This assumption abstracts from the fact that in order to cope with fluctuations in earnings and risk-weighted assets banks in general need to hold more capital than required by regulators. ${ }^{13}$ Under the Basel III agreement, banks are required to increase the regulatory common equity ratio to $4.5 \%$ by 2015. Taking the MAG assumption of no discretionary capital buffers at its face value would mean that the banking sector as a whole would not need to increase its capital level from the current benchmark of $5.7 \%$ until 2015 or could even afford a 1.2 percentage point drop in capitalization. In contrast, at the other extreme the present study considers that banks will fully maintain their discretionary capital buffers above the regulatory minima. Consequently, to meet the Basel III requirements the common equity ratio will need to rise by 1.2 percentage points on average across the three main OECD economies until 2015 and by about 3.7 percentage points until 2019. As a consequence, the calculated impact of Basel III on annual GDP growth presented in this study stands in a higher range of -0.05 to -0.15 percentage point, which is almost three times as much as the MAG's assessment ${ }^{14}$ of -0.03 to -0.05 percentage point.

\footnotetext{
12. Bank for International Settlements (2010): “Assessing the macroeconomic impact of the transition to stronger capital and liquidity requirements - Interim Report", Basel.

13. Banks also tend to hold more capital than required by regulators in order to gain a more favourable access to credit markets. This is particularly tends to be true for smaller and medium-sized banks and for banks operating in developing or emerging markets.

14. Bank for International Settlements (2010): “Assessing the macroeconomic impact of the transition to stronger capital and liquidity requirements - Final Report", Basel.
} 


\section{Other factors related to the Basel III macroeconomic impact}

\section{Monetary Policy}

16. The macroeconomic impact estimated above assumes no response from monetary policy but, to the extent that the latter will no longer be constrained by the zero lower bound, it could be used to reduce the impact of Basel III. Table 9 below shows the estimated macroeconomic impact of a reduction in monetary policy rates of 100 basis points. Considering the average coefficients from Table 9, a macroeconomic impact of Basel III on the annual GDP growth of -0.05 to -0.15 percentage point could be offset by an average reduction (or delayed increase) in monetary policy rates of about 30 to 80 basis points.

Table 9. Macroeconomic impact of a 100 basis point reduction in policy rates

\begin{tabular}{|c|c|c|c|c|c|c|}
\hline & \multicolumn{5}{|c|}{$\begin{array}{c}\text { GDP level } \\
\text { (percentages) }\end{array}$} & \multirow{2}{*}{$\begin{array}{c}\text { GDP growth } \\
\text { (percentage points) } \\
\text { annual } \\
\end{array}$} \\
\hline & Year 1 & Year 2 & Year 3 & Year 4 & Year 5 & \\
\hline United States & 0.10 & 0.40 & 0.70 & 1.00 & 1.20 & 0.24 \\
\hline Euro area & 0.00 & 0.10 & 0.40 & 0.60 & 0.90 & 0.18 \\
\hline Japan & 0.00 & 0.20 & 0.30 & 0.70 & 0.80 & 0.16 \\
\hline Average (simple) & 0.03 & 0.23 & 0.47 & 0.77 & 0.97 & 0.19 \\
\hline Average (GDP weighted) & 0.04 & 0.25 & 0.52 & 0.80 & 1.02 & 0.20 \\
\hline
\end{tabular}

Note: $\quad$ The numbers include international spillover effects among the three economies. The spillover effect on GDP level in the 5th year is about $-0.1 \%$ for the United Sates, $-0.2 \%$ for the euro area, and $-0.3 \%$ for Japan.

Source: OECD New Global Model, Authors' calculations.

\section{Funding Costs}

17. The assumption of the accounting model described in Section II that the costs of equity and debt are constant could be considered as conservative. With more capital, banks should at least in principle become safer; therefore, the cost of funding could decrease as a consequence of higher capital levels. Utilizing the accounting identity in Equation (4) shows that a 1.4 percentage point drop in the required return on bank equity would be enough to offset the impact on the overall bank funding costs of a one percentage point increase in bank capital. Considering the actual Basel III capital requirements, their impact on bank funding costs could be neutralized by a fall in the required return on equity of 1.7 to 5.2 percentage points. This estimate assumes that creditor returns would not be affected; relaxing this assumption would lead to an indeterminate Equation (5) with two unknowns. However, to the extent that the cost of borrowing would also fall as banks become better capitalised, the estimated figure above can be considered as a maximum necessary change in return on equity to nullify the macroeconomic impact of Basel III.

$$
\begin{aligned}
& r_{t}^{\mathrm{L}} \times \mathrm{L}+\mathrm{r}_{\mathrm{t}}^{\mathrm{E}} \times \mathrm{E}=\mathrm{r}_{\mathrm{t}}^{\mathrm{L}} \times\left(\mathrm{L}-\frac{\mathrm{RWA}}{100}\right)+\mathrm{r}_{\mathrm{t}+1}^{\mathrm{E}} \times\left(\mathrm{E}+\frac{\mathrm{RWA}}{100}\right) \\
& \mathrm{r}_{\mathrm{t}}^{\mathrm{L}} \times \mathrm{L}+\mathrm{r}_{\mathrm{t}}^{\mathrm{E}} \times \mathrm{E}=\mathrm{r}_{\mathrm{t}+1}^{\mathrm{L}} \times\left(\mathrm{L}-\frac{\mathrm{RWA}}{100}\right)+\mathrm{r}_{\mathrm{t}+1}^{\mathrm{E}} \times\left(\mathrm{E}+\frac{\mathrm{RWA}}{100}\right)
\end{aligned}
$$

Legend:

L - Liabilities to Total Assets (\%)

E - Common Equity to Total Assets (\%)

RWA - Risk-weighted Assets to Total Assets (\%)

$\mathrm{r}_{\mathrm{t}}^{\mathrm{L}}-$ Cost of Borrowing $(\%)$
$\mathrm{r}_{\mathrm{t}}^{\mathrm{E}}-$ Cost of Equity $(\%)$ 


\section{Discretionary Capital Buffers}

18. Banks tend to hold considerably more capital than required by regulators (Table 10). Since regulatory requirements are not the only determining factor of actual capital levels, ${ }^{15}$ banks could potentially react to a tightening in capital requirements by partially cutting their discretionary capital buffers. Studies in this area ${ }^{16}$ show that for banks with sufficiently large capital buffers a one percentage point increase in regulatory capital requirements would translate into an increase in actual capital levels of only about 0.5 percentage point. To the extent that banks would choose to hold smaller discretionary buffers, the actual Basel III impact on bank lending spreads and macroeconomic variables might be lower compared with the estimates presented in this study. ${ }^{17}$ However, as the financial crisis has reinforced market emphasis on prudent capital decisions, banks have become less apt to reduce their discretionary capital buffers. ${ }^{18}$

Table 10. Discretionary Capital Buffers

\begin{tabular}{|c|c|c|c|c|c|c|c|}
\hline & \multicolumn{3}{|c|}{$\begin{array}{c}\text { Actual Tier } 1 \text { Capital Ratio } \\
\text { (percentages) }\end{array}$} & \multirow[t]{2}{*}{$\begin{array}{l}\text { Regulatory Minimum } \\
\text { (percentages) }\end{array}$} & \multicolumn{3}{|c|}{$\begin{array}{l}\text { Tier } 1 \text { Discretionary Buffer } \\
\text { (percentage points) }\end{array}$} \\
\hline & United States & Euro area & Japan & & United States & Euro area & Japan \\
\hline 2002 & 10.0 & 8.9 & 5.4 & 4.0 & 6.0 & 4.9 & 1.4 \\
\hline 2003 & 10.1 & 9.2 & 5.1 & 4.0 & 6.1 & 5.2 & 1.1 \\
\hline 2004 & 10.0 & 8.1 & 5.1 & 4.0 & 6.0 & 4.1 & 1.1 \\
\hline 2005 & 9.8 & 8.1 & 5.1 & 4.0 & 5.8 & 4.1 & 1.1 \\
\hline 2006 & 9.8 & 8.0 & 5.4 & 4.0 & 5.8 & 4.0 & 1.4 \\
\hline 2007 & 9.4 & 7.7 & 5.6 & 4.0 & 5.4 & 3.7 & 1.6 \\
\hline 2008 & 9.7 & 8.6 & 5.6 & 4.0 & 5.7 & 4.6 & 1.6 \\
\hline \multirow[t]{3}{*}{2009} & 11.4 & 9.4 & 6.8 & 4.0 & 7.4 & 5.4 & 2.8 \\
\hline & \multicolumn{3}{|c|}{$\begin{array}{l}\text { Actual Common Equity Ratio } \\
\text { (percentages) }\end{array}$} & $\begin{array}{l}\text { Regulatory Minimum } \\
\text { (percentages) }\end{array}$ & \multicolumn{3}{|c|}{$\begin{array}{l}\text { Common Equity Discretionary Buffer } \\
\text { (percentage points) }\end{array}$} \\
\hline & United States & Euro area & Japan & & United States & Euro area & Japan \\
\hline 2002 & 9.7 & 7.6 & 3.6 & 2.0 & 7.7 & 5.6 & 1.6 \\
\hline 2003 & 9.3 & 7.9 & 3.6 & 2.0 & 7.3 & 5.9 & 1.6 \\
\hline 2004 & 9.0 & 6.9 & 3.4 & 2.0 & 7.0 & 4.9 & 1.4 \\
\hline 2005 & 8.6 & 6.9 & 3.3 & 2.0 & 6.6 & 4.9 & 1.3 \\
\hline 2006 & 8.6 & 6.8 & 3.3 & 2.0 & 6.6 & 4.8 & 1.3 \\
\hline 2007 & 8.3 & 6.6 & 3.3 & 2.0 & 6.3 & 4.6 & 1.3 \\
\hline 2008 & 8.4 & 7.3 & 3.3 & 2.0 & 6.4 & 5.3 & 1.3 \\
\hline 2009 & 10.5 & 8.0 & 4.1 & 2.0 & 8.5 & 6.0 & 2.1 \\
\hline
\end{tabular}

Source: IIF, Authors' calculations.

15. In addition to the risk of a potential breach of the regulatory minimum, there are several other factors not directly related to capital regulation that affect banks' decisions about the levels of their discretionary capital buffers. For instance, banks may hold high discretionary capital buffers to get a better credit rating or favourable funding conditions on the market.

16. See for example I. Alfon, I. Argimon and P. Bascunana-Ambrós (2004), "What determines how much capital is held by UK banks and building societies"? FSA Occasional Paper 22.

17. Considering the cross-country differences, the scope for an active use of discretionary capital buffers is greater in the United Sates and the euro area than in Japan.

18. In accordance, this study assumes that banks will not reduce their discretionary capital buffers. 


\section{WORKING PAPERS}

The full series of Economics Department Working Papers can be consulted at www.oecd.org/eco/workingpapers/

843. The policy and institutional drivers of economic growth across OECD and non-OECD economies: new evidence from growth regressions

(February 2011) by Romain Bouis, Romain Duval and Fabrice Murtin

842. $\quad$ Limiting Long-Term Unemployment and Non-Participation in Sweden (February 2011) by Niels-Jakob Harbo Hansen

841. Enhancing the cost-effectiveness of climate change mitigation policies in Sweden (February 2011) by Stéphanie Jamet

840. Policies towards a sustainable use of water in Spain

(January 2011) by Andrés Fuentes

839. Increasing public sector efficiency in Slovakia

(January 2011) by Felix Hüfner

838. Raising education outcomes in Switzerland

(January 2011) by Andrés Fuentes

837. The Price Responsiveness of Housing Supply in OECD Countries

(January 2011) by Aida Caldera Sánchez and Åsa Johansson

836. Housing markets and structural policies in OECD countries

(January 2011) by Dan Andrews, Aida Caldera Sánchez and Åsa Johansson

835. Raising potential growth after the crisis: A quantitative assessment of the potential gains from various structural reforms in the OECD area and beyond

(January 2011) by Romain Bouis and Romain Duval

834. The GDP impact of reform: a simple simulation framework

(January 2011) by Sebastian Barnes, Romain Bouis, Philippe Briard, Sean Dougherty and Mehmet Eris

833. Improving the flexibility of the Dutch housing market to enhance labour mobility (January 2011) by Jens Høj

832. Making the Dutch pension system less vulnerable to financial crises

(January 2011) by Jens Høj

831. Real house prices in OECD countries: the role of demand shocks and structural policy factors

(December 2010) by Dan Andrews

830. International financial integration and the external positions of euro area countries

(December 2010) by Philip R. Lane 
829. Improving fiscal performance through fiscal councils

(December 2010) by Robert Hagemann

828. Minimising risks from imbalances in European banking

(December 2010) by Sebastian Barnes, Philip Lane and Artur Radziwill

827. Resolving and avoiding unsustainable imbalances

(December 2010) by Sebastian Barnes

826. Current account imbalances in the euro area: a comparative perspective (December 2010) by Sebastian Barnes, Jeremy Lawson and Artur Radziwill

825. Does fiscal decentralisation strengthen social capital? Cross-country evidence and the experiences of Brazil and Indonesia

(December 2010) by Luiz de Mello

824. Fiscal decentralisation and public investment: The experience of Latin America

(December 2010) by Luiz de Mello

823. Product market regulation and competition in China

(December 2010) by Paul Conway, Richard Herd, Thomas Chalaux, Ping He and Jianxun Yu

822. Reforming China's monetary policy framework to meet domestic objectives

(December 2010) by Paul Conway, Richard Herd and Thomas Chalaux

821. Regulatory reforms to unlock long-term growth in Turkey

(December 2010) by Rauf Gönenç and Łukasz Rawdanowicz

820. After the crisis: mitigating risks of macroeconomic instability in Turkey

(December 2010) by Łukasz Rawdanowicz

819. The 2008-09 crisis in Turkey: performance, policy responses and challenges for sustaining the recovery

(December 2010) by Łukasz Rawdanowicz

818. Fiscal-consolidation strategies for Canadian governments

(November 2010) by Yvan Guillemette

817. The land transport sector: policy and performance

(November 2010) by Jan Persson and Daeho Song

816. A simple model of the relationship between productivity, saving and the current account (November 2010) by Jean-Marc Fournier, Isabell Koske

815. The impact of structural policies on saving, investment and current accounts (November 2010) by Clovis Kerdrain, Isabell Koske, Isabelle Wanner 